\title{
Land preparation and vegetation type jointly determine soil conditions after long-term land stabilization measures in a typical hilly catchment, Loess Plateau of China
}

\author{
Yang Yu ${ }^{1,2} \cdot$ Wei Wei ${ }^{1,3} \cdot$ Liding Chen ${ }^{1}$ Tianjiao Feng ${ }^{1,4} \cdot$ Stefani Daryanto $^{3}$. \\ Lixin Wang ${ }^{3}$
}

Received: 11 March 2016 / Accepted: 25 June 2016 / Published online: 8 July 2016

(C) Springer-Verlag Berlin Heidelberg 2016

\begin{abstract}
Purpose Land preparation (e.g., leveled ditches, leveled benches, adversely graded tableland, and fish-scale pits) is one of the most effective ecological engineering practices to reduce water erosion in the Loess Plateau, China. Land preparation greatly affects soil physicochemical properties. This study investigated the influence of different land preparation techniques during vegetation restoration on soil conditions, which remained poorly understood to date.

Materials and methods Soil samples were collected from depths of $0-10,10-20,20-40,40-60,60-80$, and $80-$ $100 \mathrm{~cm}$, in the typical hilly watershed of Dingxi City, Loess Plateau. Soil bulk density (BD), soil organic matter (SOM), and total nitrogen (TN) were determined for different land preparations and vegetation type combinations. Fractal theory was used to analyze soil particle size distribution (PSD).

Results and discussion (1) The effect of land preparation on soil properties and PSD varied with soil depth. For each land preparation category, SOM and TN values showed a significant difference between the top soil layer and the underlying soil depths. (2) The fractal dimension of PSD showed a
\end{abstract}

Responsible editor: Hailong Wang

Wei Wei

weiwei@rcees.ac.cn

1 State Key Laboratory of Urban and Regional Ecology, Research Center for Eco-Environmental Sciences, Chinese Academy of Sciences, Beijing 100085, China

2 Research Center on Soil and Water Conservation of the Ministry of Water Resource, Beijing 10048, China

3 Department of Earth Sciences, Indiana University-Purdue University Indianapolis (IUPUI), Indianapolis 46202, USA

4 University of Chinese Academy of Sciences, Beijing 100049, China significant positive correlation with clay and silt content, but a significant negative correlation with sand content. (3) The $20 \mathrm{~cm}$ soil layer was a boundary that distinguished the explanatory factors, with land preparation and vegetation type as the controlling factors in the $0-20$ - and $20-100-\mathrm{cm}$ soil layers, respectively.

Conclusions Land preparation and vegetation type significantly influenced soil properties, with $20 \mathrm{~cm}$ soil depth being the boundary for these two factors. This study provided a foundation for developing techniques for vegetation restoration in water-limited ecosystems.

Keywords Land preparation $\cdot$ Loess Plateau $\cdot$ Soil conditions · Soil organic matter - Soil particle distribution . Vegetation restoration

\section{Introduction}

Soil is a key component of the Earth, influencing the chemical, erosional hydrological, and biological cycles, as well as providing services, goods, and resources (Keesstra et al. 2012; Berendse et al. 2015; Brevik et al. 2015). It consists of various particles with irregular shape and self-similar components, which vary spatially. One of the key physical properties of soil system is soil particle size distribution (PSD) that plays a critical role in biogeochemical processes and cycles, such as water retention and movement, soil nutrient sorption, solute transport, and soil erosion (Hillel 1980; Tyler and Wheatcraft 1989; Erskine et al. 2002; Liu et al. 2009; Xu et al. 2013; Gao et al. 2014a; Yu et al. 2015). Changes in PSD are therefore the key factor to monitor soil structure alterations and assess soil nutrient mobility. 
In the Loess Plateau of China, severe water erosion has resulted in widespread environmental degradation (Shi and Shao 2000). In order to improve the local environment, prevent soil and water loss, land preparation has become more common, particularly with the "Grain-for-Green" project. Here various land preparation types such as leveled benches, leveled ditches, adversely graded tableland, and fish-scale pits are widely used to improve vegetation restoration, conserve water, and prevent soil erosion. As a result of predominant water shortage in this region, these measures are considered essential in enhancing seedling establishment and reducing water loss at the slopes (Bergkamp 1998; Gentili et al. 2010). They are also considered important to enhance the survival rate of plants, promote positive succession in vegetation restoration, and restore degraded ecosystems (Wei et al. 2012).

Land preparation, which is ubiquitous on many hillslopes including on the Loess Plateau, has greatly affected the soil structure by reshaping vulnerable slopes and creating diverse micro-landforms (Liu et al. 2013; Mekuria and Aynekulu 2013; Mcdonagh et al. 2014). It also affects the physical, chemical, hydrological, and biological processes of the soils by changing the rate of surface runoff and removing fine particles from the soil (Kirkby and Morgan 1980). Consequently, land preparation, in combination with water erosion, often influenced soil particle distribution and related soil properties. While previous studies reported that land use changes significantly affected soil properties (Xu et al. 2013; Zhao et al. 2014; Jia and Shao 2014), fewer examined the coupling effects of land preparation technique and vegetation type on soil conditions. In addition, since the impact of land preparation on soil improvement was usually assessed through measures in only a few elected soil properties (e.g., soil organic matter, soil moisture, and total nitrogen), we still lacked information to quantify the relationship between land preparations and other key soil properties during vegetation restoration.

To address the issue, we tried to use fractal theory, a method to model soil disruption processes such as aggregate breakdown induced by either human or natural disturbances (Martınez-Mena et al. 1999; Lyu et al. 2015). It can be used to (i) describe soil physical properties (e.g., soil bulk density, pore size distribution, particle size distribution and soil microtopography), (ii) model soil physical processes (e.g. water and solutes transport), and (iii) quantify soil spatial variability (e.g., quantify distributions of soil properties and processes) (Perfect and Kay 1995) in soil and tillage research. Fractal dimension of soil particles has also been used to characterize soil PSD and there have been numerous studies that applied fractal theory for understanding the link between PSD and soil structure, such as the influence of land use types on the fractal dimensions of PSD in the Tibetan Plateau of China (Wang et al. 2006), the use of multifractal dimensions to describe soil PSD under different land use categories of the semi-arid Loess
Plateau (Wang et al. 2008), and the monitoring of soil degradation in arid ecosystems to control desertification process $(\mathrm{Su}$ et al. 2004). Paz-Ferreiro et al. (2010) evaluated soil PSD using multifractal parameters under various management systems and demonstrated that multifractal analysis was useful for detecting the similarity of PSDs. Fractal theory is therefore an effective method for assessing the impacts of different land use pattern changes on soils.

Although soil structure has been well studied using fractal theory in different ecosystems, information about the influence of land preparation techniques on the fractal dimensions of soils is limited. In the present study, land preparation and vegetation-induced changes in PSD and soil fractal dimension were investigated in relation to changes in soil organic matter (SOM), bulk density (BD), and total nitrogen (TN) in the semi-arid area of the Loess Plateau. The objectives of this study were to (1) detect changes of soil properties in different soil depths under different land preparations and (2) determine the effect of land preparations and vegetation types on soil properties during vegetation restoration.

\section{Material and methods}

\subsection{Study site}

The study was conducted in the Longtan catchment $\left(35^{\circ} 43^{\prime} \mathrm{N}\right.$ and $104^{\circ} 27^{\prime}$ E), Dingxi City, Gansu Province, China (Fig. 1). The Longtan catchment is situated in the western part of the Loess Plateau with mean annual air temperature of $6.8^{\circ} \mathrm{C}$. The catchment has a typical hilly-gully geomorphology, with elevations ranging from about 1840 to $2260 \mathrm{~m}$, and covering the area of $16.1 \mathrm{~km}^{2}$. The mean annual precipitation is $386 \mathrm{~mm}$ (i.e., long-term average between 1961 and 2006), with more than $60 \%$ of rain falls during the three summer months (July to September). Thunderstorms often occur around this period, causing severe soil erosion. The main soil type is loessal soil, with poor soil water field capacity $\left(0.180-0.240 \mathrm{~g} \mathrm{~g}^{-1}\right.$ dry soil) and a low organic matter content $\left(0.2-2.9 \mathrm{~g} \mathrm{~g}^{-1}\right.$ dry soil). The wilting point is approximately $0.054 \mathrm{~g} \mathrm{~g}^{-1}$ dry soil and soil thickness varies from 40 to $60 \mathrm{~m}$ (Yang et al. 2014).

The catchment consists of coniferous forests, sparse shrubland, native grassland, pasture grassland, farmland, and abandoned cropland. Revegetation began in the 1980s on poor and steep cultivated lands that had low crop yields. With the implementation of the Grain-for-Green project, Chinese Pine (Pinus tabulaeformis), purple alfalfa (Medicago sativa), sea buckthorn (Hipporhae rhamnoides), and littleleaf peashrub (Caragana microphylla) were widely used for vegetation restoration. The dominant natural plant species are bunge needlegrass (Stipa bungeana) and common leymus (Leymus secalinus). Furthermore, the main introduced plant species are 
Fig. 1 Location of the study site, Longtan Catchment, Loess Plateau of China

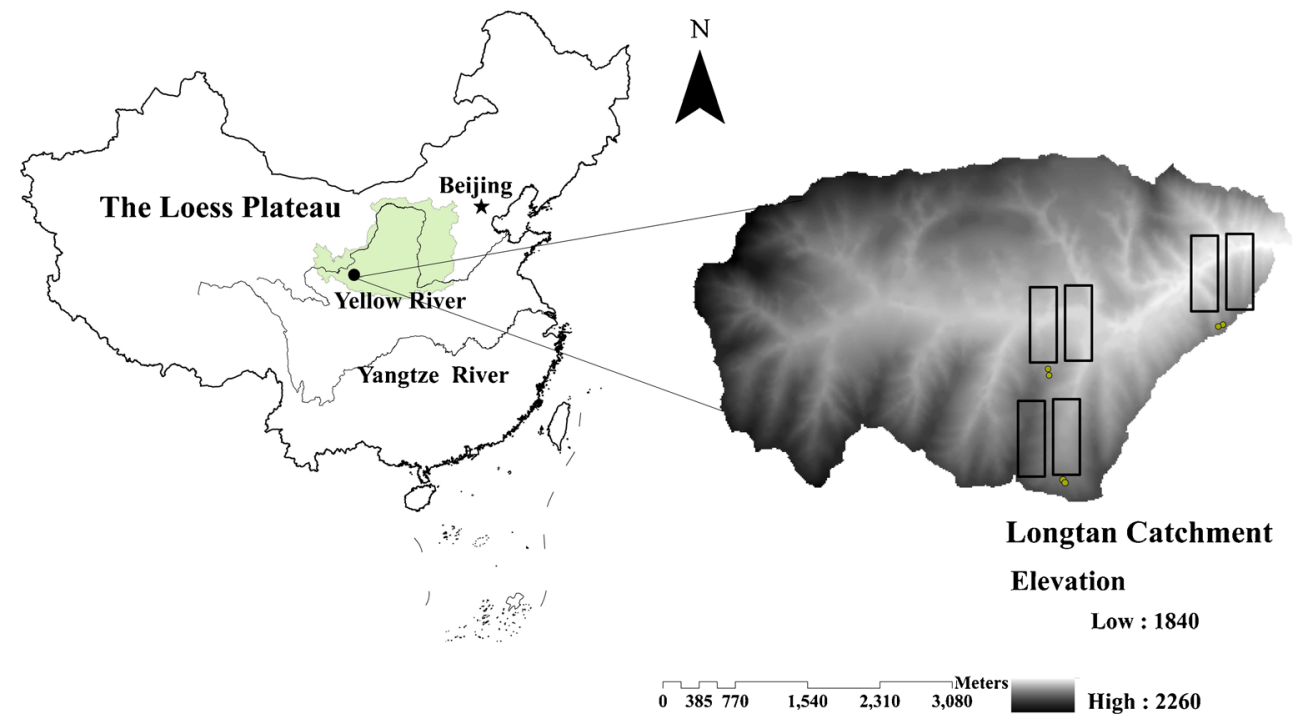

Chinese red pine (Pinus tabulaeformis), Siberian apricot (Armeniaca sibirica), Chinese arborvitae (Platycladus orientalis), and alfalfa (M. sativa). Finally, the major crops here are potato (Solanum tuberosum), soybean (Vigna angularis), and maize (Zea mays). Overall, the typical landscape pattern of the Longtan watershed is a patchy mosaic of different vegetation types and microtopographies.

\subsection{Field experimental design and soil sampling}

In the early spring of 2014, several typical land preparation types in the watershed were selected, including leveled benches, leveled ditches, adverse grade tables, and fish-scale pits. All of the selected land preparation categories were widely used during the implementation of vegetation restoration projects. Overall, six sites were determined as sampling areas. The six sites represented leveled benches with littleleaf peashrub (C. microphylla), leveled ditches with Siberian apricot (Armeniaca sibirica), adverse graded tableland with Chinese arborvitae (Platycladus orientalis) and fish-scale pits with Chinese Pine (Pinus tabulaeformis), fish-scale pits with Chinese arborvitae (Platycladus orientalis), and adverse grade tableland with Chinese Pine (Pinus tabulaeformis) (Fig. 2). Leveled benches-C. microphylla and adversely graded tableland-Platycladus orientalis were built at 1984, fish-scale pitsPinus tabulaeformis and adverse grade tableland-Pinus tabulaeformis were constructed at 1972, and leveled ditchesA. sibirica and fish-scale pits-Platycladus orientalis were established in 2003, respectively. All six sites had similar elevation and the description of each land preparations were shown in Table 1.

At each site, six sampling plots were selected randomly, with a minimum distance of $3 \mathrm{~m}$ between the plots to minimize sampling error. In each sampling plot, soil samples were collected separately with a soil auger at depths of $0-10,10-20,20-40,40-60,60-80$, and $80-100 \mathrm{~cm}$. Soil bulk density of each soil layer was measured using the core method (stainless steel cylinders with a volume of $100 \mathrm{~cm}^{3}$ ). All samples were then sealed and taken to the laboratory for further analysis. The field soil sampling was completed in the growing season of 2014.

\subsection{Laboratory and laser diffraction analysis}

In the laboratory, all soil samples were air-dried and visible plant materials were carefully removed. One part of the samples was passed through a $2 \mathrm{~mm}$ sieve for particle size distribution analysis and the other part was passed through a $0.25 \mathrm{~mm}$ sieve for SOM and TN measurement. The SOM was determined by dry combustion at $500{ }^{\circ} \mathrm{C}$ (Storer 1984) while the TN concentration was measured using the Kjeldahl procedure (Sparks et al. 1996).

For PSD determination, soil samples were pretreated with $6 \% \mathrm{H}_{2} \mathrm{O}_{2}$ in order to remove organic matter and HCL was added to eliminate carbonates and oxides. The samples were then soaked in distilled water for $24 \mathrm{~h}$. After removal from the distilled water, samples were then chemically dispersed in $0.4 \%$ Calgon and mechanically dispersed in an ultrasonic bath for $5 \mathrm{~min}$. After pretreatment, the samples were analyzed by a laser diffraction technique by using a Mastersizer 2000 (Malvern Instruments, Malvern, England). Soil particle size was classified as clay $(<2 \mu \mathrm{m})$, silt $(2-50 \mu \mathrm{m})$, and sand $(50-2000 \mu \mathrm{m})$ based on the USDA system of soil texture classification.

\subsection{Soil fractal model}

The mass fractal dimension $\left(D_{\mathrm{m}}\right)$ value of soil PSD was calculated in terms of the volume distribution of the soil particle 
Fig. 2 Land use map and sketch on land preparation types of the catchment

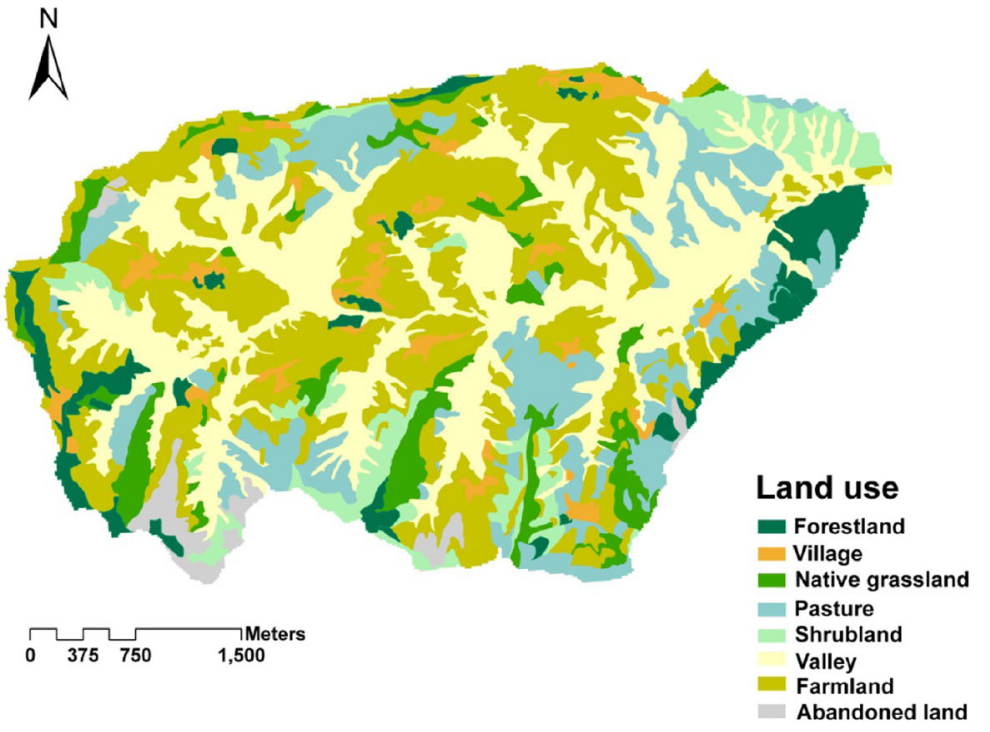

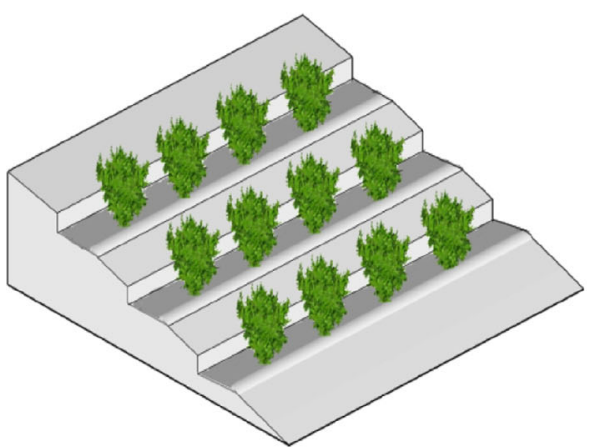

Leveled benches-C. microphylla

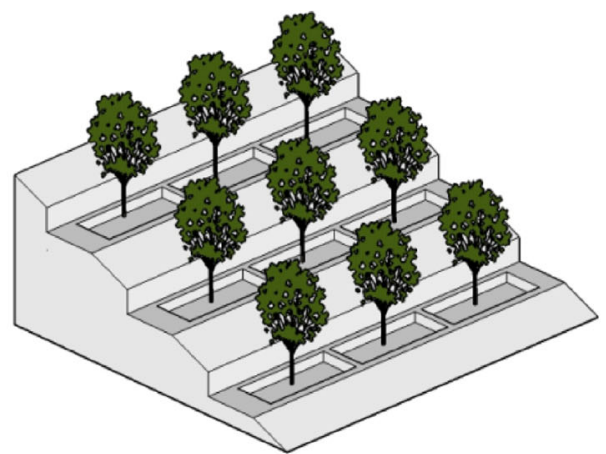

Leveled ditches-M. sativa

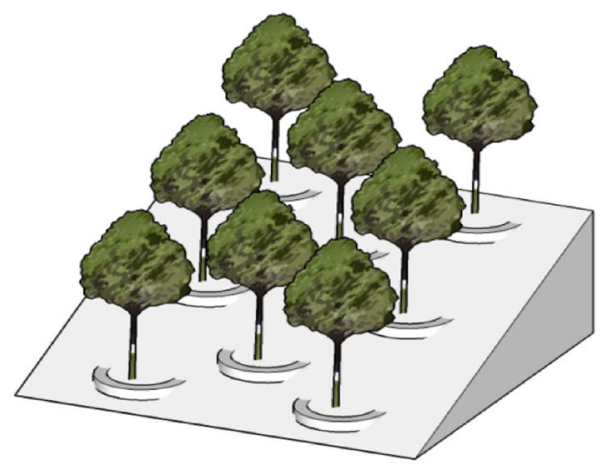

Fish-scale pits-P. tabulaeformis

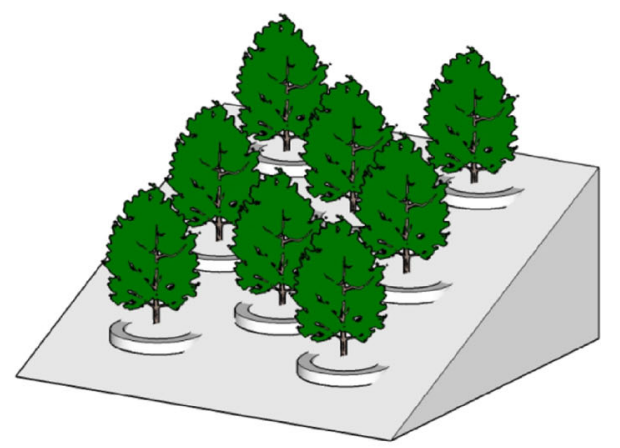

Fish-scale pits- $P$. orientalis

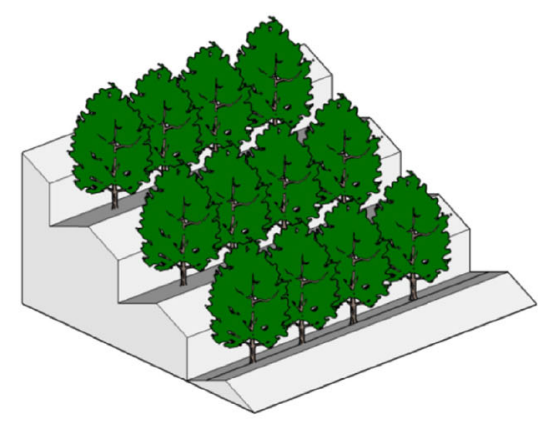

Adversely graded tableland- $P$. orientalis

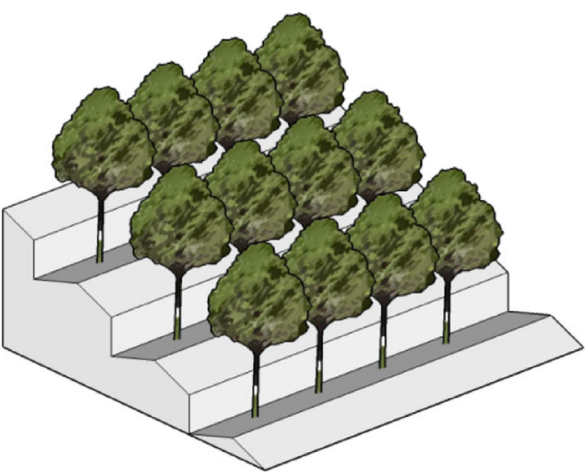

Adversely graded tableland- $P$. tabulaeformis 


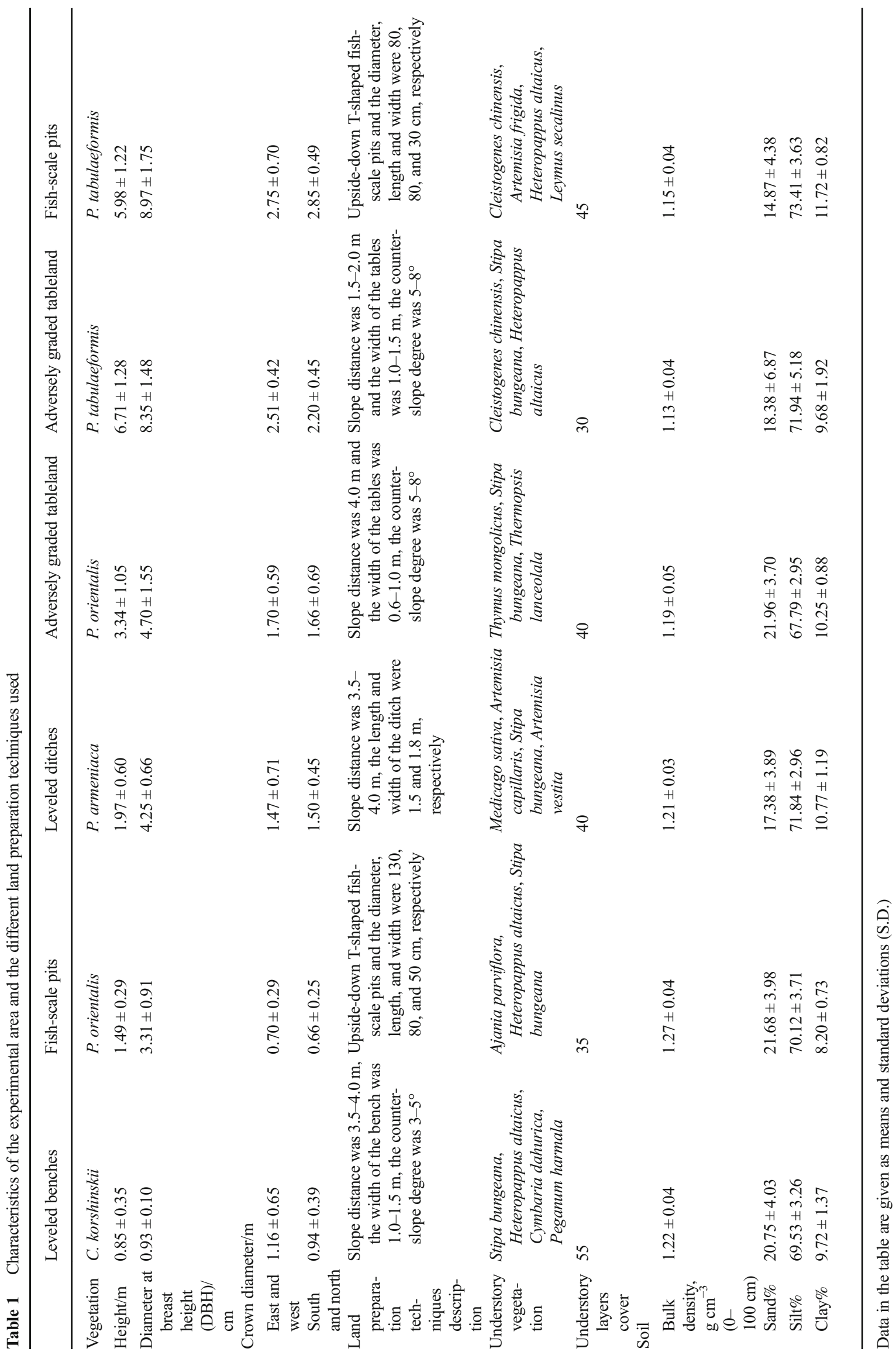


size. This model has been widely used in soil science using the following equation (Gao et al. 2014b):

$$
\frac{V\left(r<R_{i}\right)}{V_{\mathrm{T}}}=\left(\frac{R_{i}}{R_{\max }}\right)^{3-D}
$$

where $r$ is the soil particle size, $R_{i}$ is the soil particle size of grade $i$ in the particle size grading, $V\left(r<R_{i}\right)$ is the volume of soil particle size less than $R_{i}, R_{\max }$ is the maximum diameter of the soil particles, $V_{\mathrm{T}}$ is the total volume of soil particles, and $D$ is the volume-based fractal dimension.

After taking the logarithm of both sides of Eq. (1), we derived Eq. (2) to get the $D$ value using the following equation:

$D=3-\frac{\log V\left(r<R_{i}\right) / V_{T}}{\log \left(R_{i} / R_{\max }\right)}$

\subsection{Data analysis}

Means and standard deviations of the selected soil properties of the different land preparations and soil depths were determined. Analyses of variance (ANOVA) on selected properties and PSD were conducted using the MIXED procedure in SAS. This procedure used restricted maximum likelihood estimates of the variance components and computed Wald-type $F$-statistics using generalized least squares (GLSE). MultiANOVA was used to identify the effects of depth, land preparations, vegetation, and their interaction on soil properties; the differences in soil properties and PSD between different land preparations and depths were compared using one-way ANOVA. If there were significant differences in the Wald $F$ statistics at $P \leq 0.05$, treatment means were then compared using a least significant different (LSD) test. Meanwhile, the PROG REG procedure with the RSQUARE selection method was used for regression analyses (SAS 2002). In addition, redundancy analyses (RDA) were performed with R software version 3.2.0 (R Core Team 2013), with the main focus on the relationships between the soil conditions and the factors influencing them (land preparation and vegetation). The soil properties were quantitative response variables in these analyses; the explanatory variables included the categorical variables, land preparations with soil depth and vegetation types. In order to distinguish the influence of land preparation and vegetation on soil properties, we used dummy variables (absence or presence) to represent land preparation and vegetation variables. The raw data were factorized before the RDA analyses, and the significance of the variables was tested with Monte Carlo simulations.

\section{Results}

\subsection{BD, SOM, and TN variations under different land preparations}

Soil BD, SOM, and TN differed significantly among different land preparations and soil depths $(P<0.05$; Table 2$)$. Adversely graded tableland-Pinus tabulaeformis soils had the lowest overall $\mathrm{BD}$ values $\left(1.13 \mathrm{~g} \mathrm{~cm}^{-3}\right)$, whereas the fish-scale pits-Platycladus orientalis soils had the highest $\left(1.27 \mathrm{~g} \mathrm{~cm}^{-3}\right)$. The median BD was found in the leveled ditched soils. While fish-scale pits-Platycladus orientalis soils consistently showed the highest BD values across different soil depths in comparison with the other land preparations, different vegetation types of the same land preparation led to different $\mathrm{BD}$ values, depending on soil depths (Table 3). For example, in the top soil layer $(0-40 \mathrm{~cm})$ of the adversely graded tableland, BD values of Platycladus orientalis soils were significantly higher than for Pinus tabulaeformis soils. In addition, the SOM values below the depth of $40 \mathrm{~cm}$ were similar among the different land preparations, and all were significantly lower than the surface layer $(0-20 \mathrm{~cm})$ in each plot $(P<0.05)$. Finally, the TN values significantly differed between the top soil layer and the underlying soil depths. The leveled benches-C. microphylla land preparation type showed the highest $\mathrm{TN}$ value $\left(0.64 \mathrm{~g} \mathrm{~kg}^{-1}\right)$, whereas it was lowest for the adversely graded tableland-Platycladus orientalis combination $\left(0.36 \mathrm{~g} \mathrm{~kg}^{-1}\right)$.

\subsection{PSD and fractal features}

The percentage of clay, silt, and sand significantly differed among different land preparation types and soil depths
Table 2 Results of MultiANOVA for the effect of soil depth, land preparations, and vegetation type on $\mathrm{BD}, \mathrm{SOM}$, and TN

\begin{tabular}{llll}
\hline & $\mathrm{BD} / \mathrm{g} \mathrm{cm}^{-3}$ & $\mathrm{SOM} / \mathrm{g} \mathrm{kg}^{-1}$ & $\mathrm{TN} / \mathrm{g} \mathrm{kg}^{-1}$ \\
\hline Depth & $<0.001$ & $<0.001$ & $<0.001$ \\
Land preparation & 0.004 & 0.017 & 0.011 \\
Vegetation & 0.002 & 0.008 & 0.004 \\
Land preparation $\times$ vegetation & 0.035 & 0.040 & 0.014 \\
Depth $\times$ land preparation $\times$ vegetation & 0.011 & 0.009 & 0.037 \\
\hline
\end{tabular}


Table 3 Variations in bulk density (BD), soil organic matter $(\mathrm{SOM})$, and total nitrogen $(\mathrm{TN})$ among the different land preparation-vegetation type combinations

\begin{tabular}{|c|c|c|c|c|}
\hline Land preparations & $\begin{array}{l}\text { Depth/ } \\
\mathrm{cm}\end{array}$ & $\mathrm{BD} / \mathrm{g} \mathrm{cm}^{-3}$ & $\mathrm{SOM} / \mathrm{g} \mathrm{kg}^{-1}$ & $\mathrm{TN} / \mathrm{g} \mathrm{kg}^{-1}$ \\
\hline \multirow[t]{6}{*}{ Leveled benches-C. microphylla } & $0-10$ & $1.22 \pm 0.07 \mathrm{abB}$ & $20.19 \pm 0.50 \mathrm{aB}$ & $1.12 \pm 0.09 \mathrm{aA}$ \\
\hline & $10-20$ & $1.16 \pm 0.02 b C$ & $15.85 \pm 2.85 \mathrm{bAB}$ & $0.88 \pm 0.16 \mathrm{bA}$ \\
\hline & $20-40$ & $1.18 \pm 0.03 \mathrm{bAB}$ & $13.90 \pm 3.46 \mathrm{bcAB}$ & $0.62 \pm 0.39 \mathrm{cAB}$ \\
\hline & $40-60$ & $1.26 \pm 0.02 \mathrm{aB}$ & $12.26 \pm 3.35 \mathrm{cA}$ & $0.46 \pm 0.26 \mathrm{cA}$ \\
\hline & $60-80$ & $1.27 \pm 0.05 \mathrm{aB}$ & $11.01 \pm 0.22 \mathrm{cA}$ & $0.36 \pm 0.15 \mathrm{cA}$ \\
\hline & $80-100$ & $1.22 \pm 0.03 \mathrm{abA}$ & $11.64 \pm 1.21 \mathrm{cA}$ & $0.41 \pm 0.24 \mathrm{cA}$ \\
\hline \multirow[t]{6}{*}{ Fish-scale pits- $P$. orientalis } & $0-10$ & $1.29 \pm 0.02 \mathrm{aC}$ & $12.45 \pm 1.18 \mathrm{aD}$ & $0.60 \pm 0.06 \mathrm{aB}$ \\
\hline & $10-20$ & $1.31 \pm 0.05 \mathrm{aD}$ & $10.62 \pm 0.12 \mathrm{bB}$ & $0.40 \pm 0.02 \mathrm{abBC}$ \\
\hline & $20-40$ & $1.26 \pm 0.04 \mathrm{aB}$ & $11.18 \pm 1.59 \mathrm{bAB}$ & $0.32 \pm 0.02 \mathrm{bB}$ \\
\hline & $40-60$ & $1.22 \pm 0.06 \mathrm{aAB}$ & $9.78 \pm 0.22 \mathrm{bA}$ & $0.29 \pm 0.01 \mathrm{bA}$ \\
\hline & $60-80$ & $1.26 \pm 0.02 \mathrm{aB}$ & $10.04 \pm 0.22 \mathrm{bA}$ & $0.28 \pm 0.02 \mathrm{bA}$ \\
\hline & $80-100$ & $1.26 \pm 0.01 \mathrm{aA}$ & $10.88 \pm 2.31 \mathrm{bA}$ & $0.28 \pm 0.02 \mathrm{bA}$ \\
\hline \multirow[t]{6}{*}{ Leveled ditches-M. sativa } & $0-10$ & $1.15 \pm 0.02 \mathrm{bBC}$ & $16.01 \pm 1.84 \mathrm{aC}$ & $0.79 \pm 0.10 \mathrm{aB}$ \\
\hline & $10-20$ & $1.21 \pm 0.08 \mathrm{abC}$ & $10.48 \pm 0.19 \mathrm{bB}$ & $0.56 \pm 0.12 \mathrm{bB}$ \\
\hline & $20-40$ & $1.22 \pm 0.02 \mathrm{abB}$ & $11.44 \pm 1.14 \mathrm{bAB}$ & $0.48 \pm 0.22 \mathrm{bcAB}$ \\
\hline & $40-60$ & $1.24 \pm 0.04 \mathrm{aB}$ & $11.20 \pm 0.46 \mathrm{bA}$ & $0.38 \pm 0.08 \mathrm{bcA}$ \\
\hline & $60-80$ & $1.22 \pm 0.03 \mathrm{abAB}$ & $11.24 \pm 0.59 \mathrm{bA}$ & $0.31 \pm 0.02 \mathrm{bcA}$ \\
\hline & $80-100$ & $1.22 \pm 0.02 \mathrm{abA}$ & $11.21 \pm 0.22 \mathrm{bA}$ & $0.45 \pm 0.21 \mathrm{cA}$ \\
\hline \multirow{6}{*}{$\begin{array}{l}\text { Adversely graded tableland- } \\
\quad \text { P. orientalis }\end{array}$} & $0-10$ & $1.15 \pm 0.10 \mathrm{aB}$ & $15.51 \pm 1.85 \mathrm{aD}$ & $0.67 \pm 0.09 \mathrm{aB}$ \\
\hline & $10-20$ & $1.17 \pm 0.05 \mathrm{aC}$ & $12.45 \pm 0.77 \mathrm{bB}$ & $0.34 \pm 0.04 \mathrm{bC}$ \\
\hline & $20-40$ & $1.20 \pm 0.08 \mathrm{aAB}$ & $11.11 \pm 0.38 \mathrm{bB}$ & $0.32 \pm 0.06 \mathrm{bB}$ \\
\hline & $40-60$ & $1.17 \pm 0.01 \mathrm{aAB}$ & $11.62 \pm 0.59 \mathrm{bA}$ & $0.30 \pm 0.05 \mathrm{bA}$ \\
\hline & $60-80$ & $1.17 \pm 0.04 \mathrm{aA}$ & $11.36 \pm 0.44 \mathrm{bA}$ & $0.26 \pm 0.02 \mathrm{bA}$ \\
\hline & $80-100$ & $1.26 \pm 0.01 \mathrm{bA}$ & $11.11 \pm 0.38 \mathrm{bA}$ & $0.27 \pm 0.02 \mathrm{bA}$ \\
\hline \multirow[t]{6}{*}{ Fish-scale pits-P. tabulaeformis } & $0-10$ & $1.01 \pm 0.03 \mathrm{aA}$ & $24.08 \pm 2.48 \mathrm{aA}$ & $1.07 \pm 0.11 \mathrm{aA}$ \\
\hline & $10-20$ & $0.97 \pm 0.03 \mathrm{aA}$ & $18.93 \pm 2.91 \mathrm{bA}$ & $0.84 \pm 0.13 \mathrm{bA}$ \\
\hline & $20-40$ & $1.15 \pm 0.08 \mathrm{bA}$ & $14.61 \pm 2.89 \mathrm{cA}$ & $0.67 \pm 0.23 \mathrm{bcA}$ \\
\hline & $40-60$ & $1.25 \pm 0.08 \mathrm{cB}$ & $11.69 \pm 0.79 \mathrm{cdA}$ & $0.47 \pm 0.22 \mathrm{cA}$ \\
\hline & $60-80$ & $1.24 \pm 0.01 \mathrm{cAB}$ & $12.45 \pm 2.76 \mathrm{cdA}$ & $0.41 \pm 0.23 \mathrm{cA}$ \\
\hline & $80-100$ & $1.25 \pm 0.05 \mathrm{cA}$ & $10.93 \pm 0.44 \mathrm{dA}$ & $0.34 \pm 0.05 \mathrm{cA}$ \\
\hline \multirow{6}{*}{$\begin{array}{l}\text { Adversely graded tableland- } \\
\text { P. tabulaeformis }\end{array}$} & $0-10$ & $0.96 \pm 0.02 \mathrm{aA}$ & $18.34 \pm 1.43 \mathrm{aBCD}$ & $0.91 \pm 0.15 \mathrm{aAB}$ \\
\hline & $10-20$ & $1.08 \pm 0.11 \mathrm{bB}$ & $13.83 \pm 0.60 \mathrm{bB}$ & $0.52 \pm 0.07 \mathrm{bB}$ \\
\hline & $20-40$ & $1.17 \pm 0.03 \mathrm{cAB}$ & $11.64 \pm 0.38 \mathrm{bAB}$ & $0.44 \pm 0.10 \mathrm{bB}$ \\
\hline & $40-60$ & $1.16 \pm 0.06 \mathrm{cA}$ & $11.14 \pm 0.43 \mathrm{bA}$ & $0.42 \pm 0.06 \mathrm{bA}$ \\
\hline & $60-80$ & $1.19 \pm 0.02 \mathrm{cAB}$ & $11.39 \pm 0.22 \mathrm{bA}$ & $0.32 \pm 0.04 \mathrm{bA}$ \\
\hline & $80-100$ & $1.20 \pm 0.01 \mathrm{cA}$ & $11.01 \pm 0.57 \mathrm{bA}$ & $0.30 \pm 0.01 \mathrm{cA}$ \\
\hline
\end{tabular}

Data represent means and standard deviations (S.D.). Different uppercase letters indicate a significant difference among land preparation types by soil depth; different lowercase letters indicate significant differences among soil depths by land preparation type $(P<0.05)$
$(P<0.05$; Table 4$)$, although most of the soil particles was dominated by silt (i.e., 2-50 $\mu \mathrm{m}$ ) for all land preparation types, as typically found in loess soils (Table 5). In the surface soil, the clay content of the leveled ditches- $A$. sibirica combination and the fish-scale pitsPinus tabulaeformis was significantly higher than other land preparation types. For the overall $0-100 \mathrm{~cm}$ depth, the fish-scale pits-Pinus tabulaeformis combination had the highest average clay content (Table 5).

The leveled ditches-A. sibirica soils had the highest surface soil layer fractal dimension values, followed by the fish-scale pits-Pinus tabulaeformis combination, and the adversely graded tableland-Platycladus orientalis. The fish-scale pitsPlatycladus orientalis surface soil layer had the lowest fractal 
Table 4 Results of MultiANOVA for the effect of soil depth, land preparations, and vegetation type on clay, silt, sand, and $D_{\mathrm{m}}$

\begin{tabular}{lllll}
\hline & $\begin{array}{l}\text { Clay }(<2 \mu \mathrm{m}) \\
\%\end{array}$ & $\begin{array}{l}\text { Silt }(2-50 \mu \mathrm{m}) \\
\%\end{array}$ & $\begin{array}{l}\text { Sand }(50-2000 \mu \mathrm{m}) \\
\%\end{array}$ & $D_{\mathrm{m}}$ \\
\hline Depth & 0.171 & 0.009 & 0.010 & 0.226 \\
Land preparation & 0.657 & 0.038 & 0.092 & 0.548 \\
Vegetation & $<0.001$ & 0.474 & 0.184 & $<0.001$ \\
Land preparation $\times$ vegetation & $<0.001$ & 0.219 & 0.160 & $<0.001$ \\
$\begin{array}{l}\text { Depth } \times \text { land preparation } \times \\
\quad \text { vegetation }\end{array}$ & 0.606 & 0.821 & 0.220 & 0.897 \\
\hline
\end{tabular}

dimension values. For the 10-20-cm layer, the fish-scale pitsPlatycladus orientalis fractal dimension values were also significantly lower than those in the leveled ditches- $M$. sativa and fish-scale pits-Pinus tabulaeformis soils. The fish-scale pitsPinus tabulaeformis had the highest average overall fractal dimension in the $0-100-\mathrm{cm}$ soil depth, whereas it was lowest for fish-scale pits-Platycladus orientalis. The fractal dimension values of the six land preparations were in the following order: fish-scale pits-Platycladus orientalis $<$ leveled benches-C. microphylla $<$ adversely graded tablelandPlatycladus orientalis < adversely graded tableland-Pinus tabulaeformis $<$ leveled ditches- $A$. sibirica $<$ fish-scale pitsPinus tabulaeformis.

\subsection{Relationship between fractal dimension and PSD}

The fractal dimensions had significant and positive linear relationship with clay $\left(R^{2}=0.938, P<0.001\right.$; Fig. 3$)$ and silt content $\left(R^{2}=0.513, P<0.001\right.$; Fig. 3$)$ but had significant negative relationship with sand content $\left(R^{2}=\right.$ 0.764, $P<0.001$; Fig. 3).

\subsection{RDA analysis}

There was a strong association between soil properties and the explanatory factors (land preparation and vegetation types), although their importance differed among soil depths (Fig. 4). While land preparation and vegetation significantly affected soil properties in the surface soil $(0-20 \mathrm{~cm})$, land preparation (41.6\%) was the more important driver for this soil layer compared with vegetation (37.2\%). In contrast, vegetation was the dominant factor influencing soil properties at depths below $20 \mathrm{~cm}$. Although land preparation significantly influenced soil conditions in the 20-40- and 60-80-cm soil layers, this influence was not significant in the 40-60- and 80100 -cm layers. Overall, $20 \mathrm{~cm}$ soil depth was the boundary for distinguishing the influence of the two factors, with land preparation having a major effect on soil conditions above this depth.

\section{Discussion}

\subsection{Joint effects of land preparation and vegetation on soil properties}

The knowledge of variability in soil properties is the foundation for understanding the influence of land preparation or land use on soil quality and the site-specific management practices or designs (Shukla et al. 2006). Our result showed that effect of land preparation on soil BD, SOM, and TN distribution varied with soil depth, consistent with previous studies (Wang et al. 2009; Daryanto et al. 2012). SOM is an index of soil quality that reflects soil nutrient conditions, and it is a critical parameter for evaluating land use patterns (Pulleman et al. 2000; Franzluebbers 2002). Here, the fishscale pits-Pinus tabulaeformis combination and the leveled benches- $C$. microphylla exhibited the highest SOM and highest TN levels, respectively. In contrast, the lowest SOM and TN levels were observed for fish-scale pits-Platycladus orientalis soils. SOM and TN were significantly higher in the surface soil layer than the deep soil layer, indicating that both land preparation and vegetation could improve SOM and TN content of the topsoil. Lower SOM and TN levels in the fishscale pits-Platycladus orientalis combination could be attributed to the reduced residue input as well as severe soil erosion due to limited canopy cover of the species. Meanwhile, we attributed higher $\mathrm{TN}$ in the leveled benches- $C$. microphylla soils to the $\mathrm{N}_{2}$-fixing capacity of the $C$. microphylla.

These effects of vegetation were also consistent with our results on fractal dimension. For example, the soils of the fishscale pits-Pinus tabulaeformis combination had a significantly higher fractal dimension than the fish-scale pits-Platycladus orientalis soils, most likely due to differences not only in the canopy but also the root system of the species. In our study, the projected area of the Pinus tabulaeformis crown was significantly larger than that of Platycladus orientalis. Therefore, this species was probably better at mitigating erosion through rainfall than Platycladus orientalis as canopy cover was critical in reducing runoff and soil loss. These results were consistent with other studies (Daryanto et al. 2013a, b) which indicated that vegetation canopy changed the distribution of 
Table 5 Characteristic of soil particle size distribution (PSD) and mass fractal dimension $\left(D_{\mathrm{m}}\right)$ variation of different land preparation techniques

\begin{tabular}{lllll}
\hline $\begin{array}{l}\text { Land preparations/depth } \\
(\mathrm{cm})\end{array}$ & Clay $(<2 \mu \mathrm{m})$ & Silt $(2-50 \mu \mathrm{m})$ & Sand $(50-$ & $D_{\mathrm{m}}$ \\
& $\%$ & $\%$ & $\%$ & \\
& $\%$ & $\%$ & $\% \mathrm{~m})$
\end{tabular}

Leveled benches-C. microphylla

$\begin{array}{ll}0-10 & 9.71 \pm 1.61 \mathrm{aB} \\ 10-20 & 9.75 \pm 1.19 \mathrm{aAB} \\ 20-40 & 9.96 \pm 1.37 \mathrm{aAB} \\ 40-60 & 9.94 \pm 1.99 \mathrm{aB} \\ 60-80 & 9.27 \pm 0.86 \mathrm{aBC} \\ 80-100 & 9.69 \pm 0.52 \mathrm{aAB}\end{array}$

$66.32 \pm 2.11 \mathrm{aB}$

$70.58 \pm 1.62 \mathrm{abA}$

$23.97 \pm 3.73 \mathrm{aB}$

$2.52 \pm 0.04 \mathrm{aBC}$

$72.63 \pm 1.81 \mathrm{bA}$

$19.68 \pm 2.81 \mathrm{abA}$

$2.54 \pm 0.03 \mathrm{aAB}$

$72.40 \pm 2.34 \mathrm{bB}$

$17.41 \pm 1.47 \mathrm{bAB}$

$2.55 \pm 0.03 \mathrm{aAB}$

$68.39 \pm 3.53 \mathrm{abB}$

$17.66 \pm 3.13 \mathrm{bAB}$

$2.55 \pm 0.04 \mathrm{aB}$

$69.02 \pm 2.65 \mathrm{abB}$

$22.34 \pm 4.22 \mathrm{abA}$

$2.52 \pm 0.03 \mathrm{aC}$

Fish-scale pits- $P$. orientalis

$\begin{array}{ll}0-10 & 7.75 \pm 0.25 \mathrm{aB} \\ 10-20 & 9.10 \pm 0.93 \mathrm{aB} \\ 20-40 & 8.61 \pm 0.34 \mathrm{aB} \\ 40-60 & 7.46 \pm 1.29 \mathrm{aC} \\ 60-80 & 7.69 \pm 1.23 \mathrm{aC} \\ 80-100 & 7.68 \pm 0.90 \mathrm{aB} \\ \text { Leveled ditches-M. sativa } & \\ 0-10 & 11.94 \pm 0.44 \mathrm{aA} \\ 10-20 & 11.22 \pm 0.54 \mathrm{abA} \\ 20-40 & 10.47 \pm 1.52 \mathrm{abB} \\ 40-60 & 10.05 \pm 0.06 \mathrm{abB} \\ 60-80 & 9.64 \pm 0.50 \mathrm{bB} \\ 80-100 & 9.70 \pm 0.57 \mathrm{bAB}\end{array}$

$62.38 \pm 3.49 \mathrm{aC}$

$21.29 \pm 2.45 \mathrm{abAB}$

$2.54 \pm 0.01 \mathrm{aB}$

$70.81 \pm 0.79 \mathrm{bA}$

$72.41 \pm 3.72 \mathrm{bA}$

$29.86 \pm 3.66 \mathrm{aA}$

$2.47 \pm 0.02 \mathrm{aC}$

$20.09 \pm 0.89 \mathrm{bA}$

$2.53 \pm 0.02 \mathrm{bB}$

$69.31 \pm 4.34 \mathrm{bBC}$

$18.98 \pm 3.55 \mathrm{bAB}$

$2.52 \pm 0.01 \mathrm{bB}$

$72.08 \pm 0.75 \mathrm{bB}$

$23.23 \pm 3.41 \mathrm{bA}$

$2.48 \pm 0.04 \mathrm{abC}$

$72.08 \pm 0.75 \mathrm{bB}$

$20.23 \pm 1.64 \mathrm{bA}$

$2.50 \pm 0.03 \mathrm{abC}$

$73.05 \pm 2.22 \mathrm{bAB}$

$19.27 \pm 2.46 \mathrm{bB}$

$2.50 \pm 0.02 \mathrm{abB}$

$74.38 \pm 2.37 \mathrm{aA}$

$13.67 \pm 2.81 \mathrm{bC}$

$2.59 \pm 0.01 \mathrm{aA}$

$72.59 \pm 2.21 \mathrm{aA}$

$16.18 \pm 2.68 \mathrm{abA}$

$2.57 \pm 0.01 \mathrm{abA}$

$70.86 \pm 1.03 \mathrm{aAB}$

$18.67 \pm 1.79 \mathrm{abAB}$

$2.56 \pm 0.03 \mathrm{abAB}$

$70.21 \pm 0.71 \mathrm{aBC}$

$19.74 \pm 0.76 \mathrm{aAB}$

$2.55 \pm 0.01 \mathrm{abB}$

$69.67 \pm 0.57 \mathrm{aB}$

$20.69 \pm 0.82 \mathrm{aA}$

$2.54 \pm 0.01 \mathrm{bBC}$

$70.06 \pm 0.30 \mathrm{aAB}$

$20.24 \pm 0.85 \mathrm{aAB}$

$2.54 \pm 0.01 \mathrm{bB}$

Adversely graded tableland- $P$. orientalis

$\begin{array}{ll}0-10 & 9.85 \pm 0.92 \mathrm{aB} \\ 10-20 & 10.68 \pm 0.73 \mathrm{aAB} \\ 20-40 & 10.05 \pm 0.69 \mathrm{aAB} \\ 40-60 & 9.97 \pm 0.34 \mathrm{aB} \\ 60-80 & 10.43 \pm 0.72 \mathrm{aB} \\ 80-100 & 10.45 \pm 0.68 \mathrm{aA}\end{array}$

$66.47 \pm 1.56 \mathrm{aBC}$

$23.67 \pm 2.46 \mathrm{aB}$

$2.53 \pm 0.02 \mathrm{aBC}$

$69.52 \pm 2.65 \mathrm{aA}$

$67.69 \pm 1.97 \mathrm{aB}$

$19.80 \pm 3.09 \mathrm{aA}$

$2.56 \pm 0.02 \mathrm{aAB}$

$66.89 \pm 1.72 \mathrm{aC}$

$68.17 \pm 2.64 \mathrm{aB}$

$67.57 \pm 0.81 \mathrm{aB}$

$22.26 \pm 2.64 \mathrm{aA}$

$2.54 \pm 0.02 \mathrm{aB}$

$23.14 \pm 2.05 \mathrm{aA}$

$2.53 \pm 0.01 \mathrm{aB}$

$21.39 \pm 4.35 \mathrm{aA}$

$2.55 \pm 0.02 \mathrm{aBC}$

Fish-scale pits-P. tabulaeformis

\begin{tabular}{lllll}
$0-10$ & $10.61 \pm 0.55 \mathrm{bA}$ & $68.45 \pm 0.95 \mathrm{aB}$ & $20.95 \pm 1.01 \mathrm{aB}$ & $2.55 \pm 0.01 \mathrm{bB}$ \\
$10-20$ & $11.31 \pm 0.70 \mathrm{abA}$ & $71.70 \pm 2.00 \mathrm{aA}$ & $16.99 \pm 2.62 \mathrm{abA}$ & $2.57 \pm 0.02 \mathrm{abA}$ \\
$20-40$ & $11.78 \pm 0.23 \mathrm{abA}$ & $72.48 \pm 5.00 \mathrm{aA}$ & $15.74 \pm 4.91 \mathrm{abB}$ & $2.59 \pm 0.01 \mathrm{abA}$ \\
$40-60$ & $12.41 \pm 2.30 \mathrm{abA}$ & $78.45 \pm 1.86 \mathrm{bA}$ & $9.13 \pm 3.56 \mathrm{cB}$ & $2.61 \pm 0.04 \mathrm{aA}$ \\
$60-80$ & $13.11 \pm 2.24 \mathrm{a}$ & $77.30 \pm 0.45 \mathrm{bA}$ & $9.59 \pm 2.59 \mathrm{cB}$ & $2.62 \pm 0.04 \mathrm{aA}$ \\
$80-100$ & $11.53 \pm 0.58 \mathrm{abA}$ & $73.80 \pm 1.33 \mathrm{abA}$ & $14.67 \pm 0.59 \mathrm{bcB}$ & $2.58 \pm 0.01 \mathrm{aA}$ \\
Adversely graded tableland- $P$. tabulaeformis & & & \\
$0-10$ & $8.31 \pm 1.55 \mathrm{aB}$ & $68.53 \pm 2.68 \mathrm{bB}$ & $23.16 \pm 4.01 \mathrm{aB}$ & $2.50 \pm 0.04 \mathrm{aC}$ \\
$10-20$ & $10.33 \pm 1.33 \mathrm{bAB}$ & $73.06 \pm 4.48 \mathrm{abA}$ & $16.61 \pm 5.77 \mathrm{bA}$ & $2.56 \pm 0.04 \mathrm{bAB}$ \\
$20-40$ & $10.63 \pm 2.61 \mathrm{bA}$ & $73.88 \pm 5.77 \mathrm{aA}$ & $15.49 \pm 1.57 \mathrm{bB}$ & $2.56 \pm 0.08 \mathrm{bAB}$ \\
$40-60$ & $10.88 \pm 0.88 \mathrm{bA}$ & $74.62 \pm 2.70 \mathrm{aA}$ & $14.50 \pm 3.58 \mathrm{bB}$ & $2.57 \pm 0.02 \mathrm{bA}$ \\
$60-80$ & $10.62 \pm 2.00 \mathrm{bA}$ & $77.00 \pm 4.97 \mathrm{aA}$ & $12.38 \pm 1.11 \mathrm{bB}$ & $2.57 \pm 0.05 \mathrm{bB}$ \\
$80-100$ & $8.07 \pm 0.34 \mathrm{aB}$ & $66.82 \pm 1.09 \mathrm{bB}$ & $25.11 \pm 1.40 \mathrm{bA}$ & $2.49 \pm 0.01 \mathrm{aB}$ \\
\hline
\end{tabular}

Data in the table represent means and standard deviations (S.D.). Different uppercase letters indicate significant differences among land preparation types by soil depth; different lowercase letters indicate significant differences among soil depths by land preparation type $(P<0.05)$ 

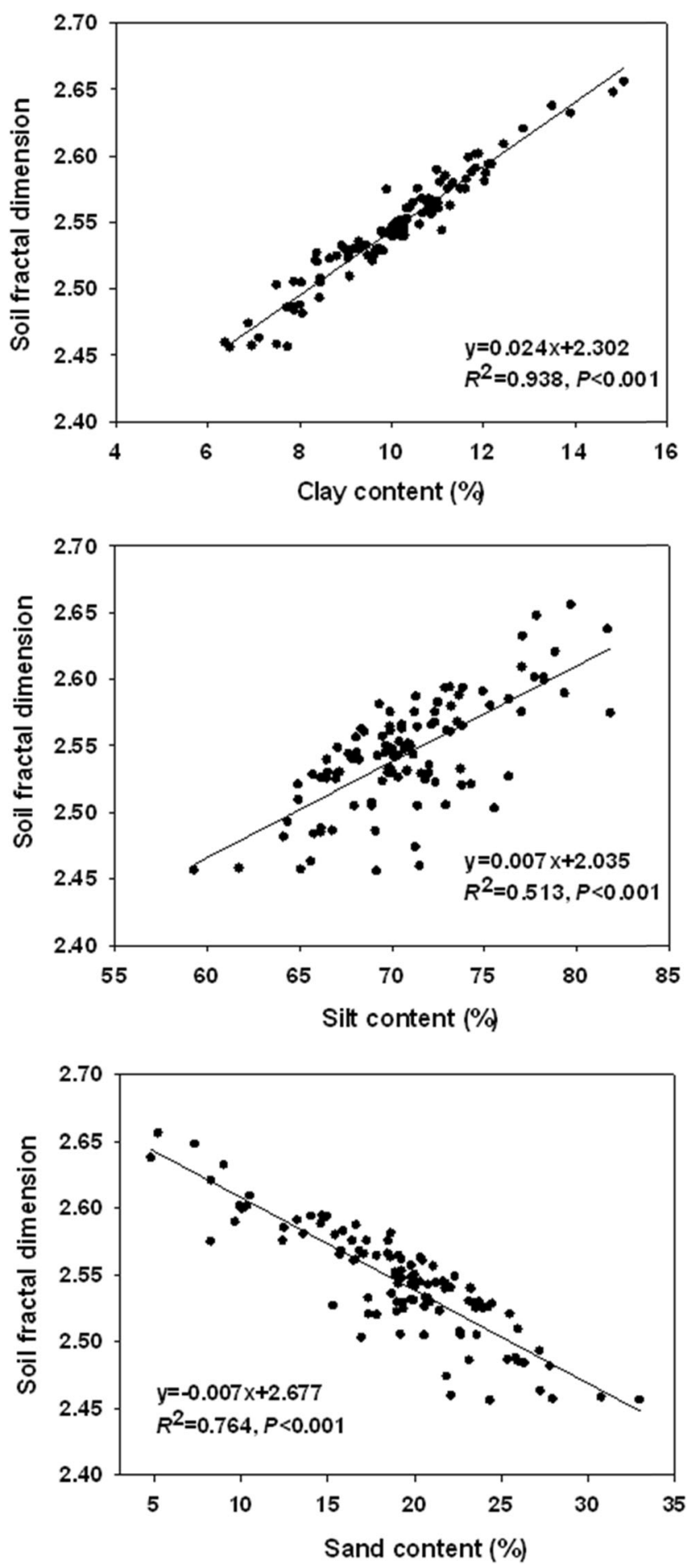

Fig. 3 Relationships between fractal dimensions of particle size distribution (PSD) and clay, silt, and sand content

soil organic matter and soil infiltrability. As plant roots penetrated the soils, they actively changed infiltration rate which consequently led to changes in PSD (Angers and Caron 1998; Zuazo and Pleguezuelo 2008). Similarly, plant roots played essential role in influencing the responses of SOM, TN, and soil texture to different land preparation types. In the deep soil layer, the amount of $\mathrm{TN}$ was generally low as mineralized

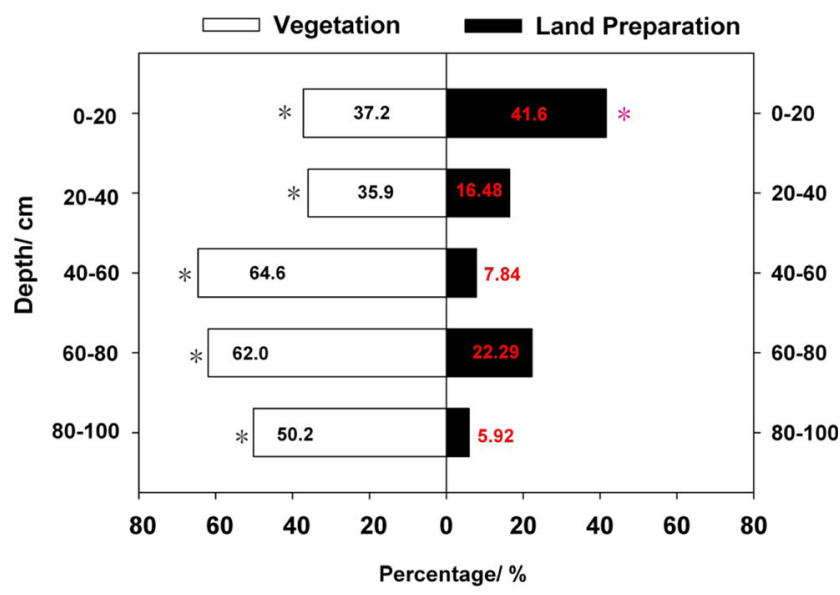

“:*” stand for significant level less than 0.05

Fig. 4 The proportion of vegetation types and land preparations contributing to the variance of the soil properties at different soil depths, based on the redundancy analysis (RDA)

organic residues were smaller compared to the amount of $\mathrm{N}$ absorbed by plant roots. Overall, land preparation can modify soil properties through abiotic influences by reducing soil water erosion, sediment transport, and runoff, whereas vegetation influences soil properties through biotic mechanisms, such as the development of canopy and root activity (Hillel 2008).

The fractal dimension was also responsive to land preparation and soil depth, indicating that both natural and managerial factors influence this indicator. Land preparation significantly affected the extent of water erosion by changing the path of water flow during rainfall events, resulting in different soil particle distributions, soil water regimes, and nutrient transportation, particularly the surface SOM and TN concentrations (Appels et al. 2011; Thompson et al. 2010; Wang et al. 2015). Water erosion occurred mainly in the surface soil layer, while land preparation techniques could decrease erosion and increase soil clay content, indicated by the higher SOM and $\mathrm{TN}$ in the surface soil. Furthermore, soil PSD was sensitive to land preparations, as significant differences in the fractal dimensions of the PSD were detected among the different land preparation types.

Our study indicated that soil texture (i.e., clay content) greatly affected the fractal dimensions of PSD by changing the amount of SOM. In loess soils, clay-rich soils can store more organic matter by forming soil humus than clay poor soils (Liu et al. 2007). SOM therefore increased when soil fractal parameter values increased and particles became less coarse and vice versa (Wang et al. 2007; Gao et al. 2014b). In the present study, the fractal dimension of PSD showed a significant positive relationship with clay and silt content, but a significantly negative relationship with sand content. In other words, higher clay and silt contents but lower sand content led to higher fractal dimension, consistent with the previous studies (Liu et al. 2009; Su et al. 2004). 


\subsection{Respective role of land preparation and vegetation}

Our RDA results indicated that land preparation techniques and the plant species growing on the sites had a great influence on the soil properties, with land preparation as the dominant factor influencing soil properties in the top $20 \mathrm{~cm}$ of the soil while vegetation types in the deeper soil layers. During vegetation restoration, land preparations have significant local impacts on the geomorphologic and hydrological dynamics. Since land preparation can affect geomorphic processes via soil water erosion (and later the vegetation type), the influence of land preparation techniques was more apparent on surface soil (Fig. 2). On the other hand, vegetation was the main factors influencing soil properties below $20 \mathrm{~cm}$, suggesting that roots play an essential role in changing soil properties as a response to different land preparations in the Loess Plateau. Roots are closely related to soil structure and pedohydrology, and play a vital role in regulating soil resistance. With increasing plant growth and successional stage, the development and decay of the roots impacted soil pore structure, soil moisture status, and soil aggregate stability (Wang et al. 2013). Our study was conducted more than 13 years after restoration. As these impacts of vegetation on soil properties (e.g., vertical distribution, SOM, TN, and biomass of the roots) usually increase with increasing restoration years (Daryanto et al. 2012; Yu and Jia 2014), it is unsurprising if greater effects of vegetation can be explained by larger influence of roots in the deeper soil after long-term land stabilization measures.

\subsection{Implications of this study and suggestions for further research}

In the hilly watershed of the Loess Plateau, the interacting pressures of anthropogenic and environmental change drive the environmental systems towards almost irreversible modifications. Both natural changes and management modify soil properties during long-term vegetation restoration projects. Our findings have important implications on soil and water conservation, environmental engineering, and ecological restoration in water-limited ecosystems. From the theoretical point of view, the aims of land preparation are to prevent runoff and water erosion, and to supply limited water for vegetation. Our study demonstrated that land preparation techniques and vegetation type jointly determine soil conditions, and that land preparation is a recommended method to improve and rehabilitate degraded ecosystems. From the practical point of view, our result indicated that $20 \mathrm{~cm}$ was the boundary layer to distinguish land preparation and plant species as the dominant factor influencing soil conditions. It is necessary to pay attention to this boundary layer during the process of land preparation engineering at the current study site.
Our results indicated that different vegetation-land preparation combinations resulted in different soil conditions, thus selecting certain vegetation-land preparation combinations rather than using random plant species could be critical for ecosystems restoration. To date, partly due to the different kinds of land preparation types and their related ecohydrological or biological responses, detailed relationships between land preparation and plant species choice had not been explored thoroughly. Although land preparation is ubiquitous among different kinds of ecosystems, the detailed mechanism underlying the influence of land preparation techniques on vegetation patterns and even ecosystem services remains unclear, including the responses of erosion processes or nutrient cycling under the coupling effects of land preparation and vegetation pattern. Hence, long-term monitoring and consecutive measurements of different land preparation types are required for future studies, to better evaluate their effects on soil properties, as well as on eco-hydrological and biological responses.

\section{Conclusions}

Our results showed that land preparation type and plant species jointly affected soil conditions in a hilly watershed in the Loess Plateau. Significant differences for major soil properties such as SOM, TN, $D_{\mathrm{m}}$, and clay, silt, and sand content were detected among different land preparation-dominant plant species combinations. The fish-scale pits-Pinus tabulaeformis and leveled benches- $C$. microphylla soils had the highest SOM and TN content, respectively. The SOM and TN in each soil depth exhibited surface aggregation under the coupling effects of land preparation techniques and vegetation type. RDA analyses showed that land preparation techniques and vegetation type significantly affected soil properties at different depth (i.e., land preparation had a major impact on the surface soil properties, whereas plant species on the deeper soil layer), considering site-specific land preparation-plant species combinations could be critical to ensure long-term land stabilization.

Acknowledgments We would like to thank Jin Chen, Xiaoping Wang, Qindi Zhang, for their generous assistance with the field work. The work was funded by the National Natural Science Foundation of China (41371123, 41501091, 41401209) and the National Advanced Project of China (2015BAC01B02). We thank the editors and two anonymous reviewers for their constructive remarks to improve the manuscript.

\section{References}

Angers DA, Caron J (1998) Plant-induced changes in soil structure: processes and feedbacks. Biogeocheistry 42: 55-72 
Appels WM, Bogaart PW, van der Zee SE (2011) Influence of spatial variations of microtopography and infiltration on surface runoff and field scale hydrological connectivity. Adv Water Resour 34:303313

Berendse F, van Ruijven J, Jongejans E, Keesstra S (2015) Loss of plant species diversity reduces soil erosion resistance. Ecosystems 18: 881-888

Bergkamp G (1998) A hierarchical view of the interactions of runoff and infiltration with vegetation and microtopography in semiarid shrublands. Catena 33:201-220

Brevik E, Cerdà A, Mataix-Solera J, Pereg L, Quinton J, Six J, Van Oost K (2015) The interdisciplinary nature of SOIL. Soil 1:117

Daryanto S, Eldridge DJ, Koen TB (2012) Soil nutrients under shrub hummocks and debris mounds two decades after ploughing. Plant Soil 351:405-419

Daryanto S, Eldridge DJ, Wang L (2013a) Ploughing and grazing alter the spatial patterning of surface soils in a shrub-encroached woodland. Geoderma 200:67-76

Daryanto S, Eldridge DJ, Wang L (2013b) Spatial patterns of infiltration vary with disturbance in a shrub-encroached woodland. Geomorphology 194:57-64

Erskine WD, Mahmoudzadeh A, Myers C (2002) Land use effects on sediment yields and soil loss rates in small basins of Triassic sandstone near Sydney, NSW, Australia. Catena 49:271-287

Franzluebbers A (2002) Soil organic matter stratification ratio as an indicator of soil quality. Soil Tillage Res 66:95-106

Gao G, Ding G, Wu B, Zhang Y, Qin S, Zhao Y, Bao Y, Liu Y, Wan L, Deng J (2014a) Fractal scaling of particle size distribution and relationships with topsoil properties affected by biological soil crusts. PLoS One 9, e88559

Gao P, Niu X, Lv S, Zhang G (2014b) Fractal characterization of soil particle-size distribution under different land-use patterns in the Yellow River Delta Wetland in China. J Soils Sediments 14:11161122

Gentili R, Armiraglio S, Rossi G, Sgorbati S, Baroni C (2010) Floristic patterns, ecological gradients and biodiversity in the composite channels (Central Alps, Italy). Flora-Morphol, Distrib, Funct Ecol Plants 205:388-398

Hillel D (1980) Fundamentals of soil physics. Academic Press, London Hillel D (2008) Soil in the environment. Academic Press, New York

Jia Y, Shao M (2014) Dynamic of deep soil moisture in response to vegetational restoration on the Loess Plateau of China. J Hydrol 519:523-531

Keesstra S, Geissen V, Mosse K, Piiranen S, Scudiero E, Leistra M, van Schaik L (2012) Soil as a filter for groundwater quality. Curr Opin Environ Sustain 4:507-516

Kirkby MJ, Morgan RPC (1980) Soil erosion. Wiley, Chichester

Liu S, Guo X, Fu B, Lian G, Wang J (2007) The effect of environmental variables on soil characteristics at different scales in the transition zone of the Loess Plateau in China. Soil Use Manag 23:92-99

Liu X, Zhang G, Heathman GC, Wang Y, Huang C (2009) Fractal features of soil particle-size distribution as affected by plant communities in the forested region of Mountain Yimeng, China. Geoderma 154:123-130

Liu S, Dong Y, Li D, Liu Q, Wang J, Zhang X (2013) Effects of different terrace protection measures in a sloping land consolidation project targeting soil erosion at the slope scale. Ecol Eng 53:46-53

Lyu X, Yu J, Zhou M, Ma B, Wang G, Zhan C, Han G, Guan B, Wu H, Li $Y$ (2015) Changes of soil particle size distribution in tidal flats in the Yellow River Delta. PLoS One 10, e0121368. doi:10.1371/journal. pone. 0121368

Martınez-Mena M, Deeks L, Williams A (1999) An evaluation of a fragmentation fractal dimension technique to determine soil erodibility. Geoderma 90:87-98
Mcdonagh J, Lu Y, Semalulu O (2014) Adoption and adaptation of improved soil management practices in the Eastern Ugandan Hills. Land Degrad Dev 25:58-70

Mekuria W, Aynekulu (2013) Exclosure land management for restoration of the soils in degraded communal grazing lands in northern Ethiopia. Land Degrad Dev 24:528-538

Paz-Ferreiro J, Vidal E, Miranda JGV (2010) Assessing soil particle-size distribution on experimental plots with similar texture under different management systems using multifractal parameters. Geoderma 160:47-56

Perfect E, Kay B (1995) Applications of fractals in soil and tillage research: a review. Soil Tillage Res 36:1-20

Pulleman M, Bouma, Van Essen E, Meijles E (2000) Soil organic matter content as a function of different land use history. Soil Sci Soc Am J 64:689-693

R Core Team (2013) R: a language and environment for statistical computing. R Foundation for Statistical Computing, Vienna

SAS Institute Inc. (2002) The SAS system for Windows. SAS Publishing, SAS Inst., Cary, NC

Shi H, Shao M (2000) Soil and water loss from the Loess Plateau in China. J Arid Environ 45:9-20

Shukla MK, Lal R, Ebinger M, Meyer C (2006) Physical and chemical properties of soils under some piñon-juniper-oak canopies in a semiarid ecosystem in New Mexico. J Arid Environ 66:673-685

Sparks DL, Page A, Helmke P, Loeppert R, Soltanpour P, Tabatabai M, Johnston C, Sumner M (1996) Methods of soil analysis. Part 3Chemical methods. Soil Science Society of America Inc

Storer DA (1984) A simple high sample volume ashing procedure for determination of soil organic matter. Commun Soil Sci Plan 15:759-772

Su YZ, Zhao HL, Zhao WZ, Zhang TH (2004) Fractal features of soil particle size distribution and the implication for indicating desertification. Geoderma 122:43-49

Thompson SE, Katul GG, Porporato A (2010) Role of microtopography in rainfall-runoff partitioning: an analysis using idealized geometry. Water Resour Res. doi:10.1029/2009WR008835

Tyler SW, Wheatcraft SW (1989) Application of fractal mathematics to soil water retention estimation. Soil Sci Soc Am J 53:987-996

Wang X, Li M, Liu S, Liu G (2006) Fractal characteristics of soils under different land-use patterns in the arid and semiarid regions of the Tibetan Plateau, China. Geoderma 134:56-61

Wang D, Fu B, Chen L (2007) Fractal analysis on soil particle size distributions under different land-use types: a case study in the loess hilly areas of the Loess Plateau, China. Acta Ecol Sin 27:3081-3089

Wang D, Fu B, Zhao W, Hu H, Wang Y (2008) Multifractal characteristics of soil particle size distribution under different land-use types on the Loess Plateau, China. Catena 72:29-36

Wang L, D'Odorico P, Okin G, Macko S (2009) Isotope composition and anion chemistry of soil profiles along Kalahari Transect. J Arid Environ 73:480-486

Wang B, Zhang G, Shi Y, Zhang X, Ren Z, Zhu L (2013) Effect of natural restoration time of abandoned farmland on soil detachment by overland flow in the Loess Plateau of China. Earth Surf Process Landf 38:1725-1734

Wang Y, Shao M, Zhang C, Han X, Mao T, Jia X (2015) Choosing an optimal land-use pattern for restoring eco-environments in a semiarid region of the Chinese Loess Plateau. Ecol Eng 74:213-222

Wei W, Chen L, Yang L, Samadani FF, Sun G (2012) Microtopography recreation benefits ecosystem restoration. Environ Sci Technol 46: 10875-10876

Xu G, Li Z, Li P (2013) Fractal features of soil particle-size distribution and total soil nitrogen distribution in a typical watershed in the source area of the middle Dan River, China. Catena 101:17-23

Yang L, Chen L, Wei W, Yu Y, Zhang H (2014) Comparison of deep soil moisture in two re-vegetation watersheds in semi-arid regions. $\mathrm{J}$ Hydrol 513:314-321

Yu Y, Jia Z (2014) Changes in soil organic carbon and nitrogen capacities of Salix cheilophila Schneid along a revegetation chronosequence in 
semi-arid degraded sandy land of the Gonghe Basin, Tibet Plateau. Solid Earth 5:1045-1054

Yu J, Lv X, Bin M, Wu H, Du S, Zhou M, Yang Y, Han G (2015) Fractal features of soil particle size distribution in newly formed wetlands in the Yellow River Delta. Sci Rep 5:10540. doi:10.1038/srep10540
Zhao F, Han X, Yang G, Feng Y, Ren G (2014) Soil structure and carbon distribution in subsoil affected by vegetation restoration. Plant Soil Environ 1:21-26

Zuazo VHD, Pleguezuelo CRR (2008) Soil-erosion and runoff prevention by plant covers. A review. Agron Sustain Dev 28:65-86 